\title{
THE EFFECT OF USING "EDMODO AND QUIPPER SCHOOL" IN BLENDED LEARNING METHOD TOWARDS STUDENTS' WRITING SKILL AT THE SECOND YEAR STUDENTS OF SMAN 1 BENGKULU TENGAH
}

\author{
Dian Permata Sari \\ Bambang Suwarno \\ Deddy Sofyan \\ University of Bengkulu
}

\begin{abstract}
This research aims to compare whether there was an effect on students' writing quality when students were taught with blended learning method, combined with Edmodo or Quipper School. This was a quasi-experimental research with 72 students at grade XI MIPA SMAN I Bengkulu Tengah, Indonesia as the samples. The experiment group was taught with Edmodo while the control group was taught with Quipper School. The instrument was a writing test. The findings of this research, with respect to the comparison of post test mean scores between the experimental group and the control group, were as follows. There was a significant difference on students' general writing ability. There were significant differences on students' writing ability in the aspects of content and language use. However, there was no significant difference.The students' responses were positive toward the use of Edmodo as a blended learning. Further studies are recommended for other school levels. It seems that Edmodo is more effective than Quipper School in writing lesson since the learning platform in Edmodo gives facilities for the students to work independently, enables them to improve their quality and has more practical, interactive, and interesting features.
\end{abstract}

Key Words: Writing ability, Edmodo, Quipper school

\begin{abstract}
ABSTRAK
Penelitian ini bertujuan untuk menemukan apakah terdapat pengaruh pada kualitas menulis siswa ketika siswa diajarkan dengan metoe pembelajaran campuran menggunakan Edmodo dan Quipper School. Penelitian ini adalah penelitian kuasi eksperimen dengan 72 siswa kelas XI MIPA SMAN 1 Bengkulu Tengah sebagai sampel penelitian ini. Hasil penelitian ini, yaitu (1) terdapat sebuah perbedaan yang signifikan pada kemampuan menulis siswa secara umum antara kelompok eksprimen, dengan menggunakan Edmodo, dan dibandingkan dengan kelompok kontrol yang diajarkan menggunakan Quipper School, (2) terdapat perbedaan signifikan pada kemampuan menulis siwa pada aspek isi dan penggunaan bahasa. Namun, tidak terdapat perbedaan pada kemampuan menulis siswa pada aspek organisasi,(3) respon siswa positif terhadap penggunan
\end{abstract}


Edmodo sebagai metode pengajaran campuran pada kemampuan menulis. Berdasarkan hasil penelitian, dapat dilihat bahwa Edmodo lebih efektif dari pada Quipper School dalam pembelajaran menulis karena platform belajar yang disediakan di Edmodo memberikan fasilitas bagi siswa untuk bekerja secara mandiri, kemudian mampu membantu siswa lebih fokus pada kualitas kerja mereka. Itu juga mungkin disebabkan oleh fitur-fiture Edmodo yang lebih praktis, interaktif, dan menarik.

Kata Kunci: Kemampuan menulis, Edmodo, Quipper school

\section{INTRODUCTION}

The use of technology in language learning, specifically writing, is no longer a new phenomenon. Teaching paradigm has radically been changed by technology which makes teaching simpler without time or space restriction (Alonso et al, 2005). Technology is also trusted to provide language learners with a great number of possibilities to enhance language learning (Dudeney \& Hockly, 2007). They specifically argue that technology, with its perpetual development, can give learners exposures, allow them to practice the knowledge, and bridge teachers to assess the learners' language ability. Westwood (2008) claims that in this information era, writing is not paper-based only, but it also uses richer media such as multimedia platforms. Applying technology in writing, which has been taught on paper especially in the past, becomes increasingly improved by the rapid development of technology.

There are many strategies that can be use to improve students' English proficiency, especially in writing skill. There are many selection of teaching strategies that can be used. It can be E-learning bases Educational Social Networking Sites. E-learning is a learning that can be done by using blended learning method that can give stimulus for students in creating active and pleasing learning. So the students can increase their proficiency in knowledge and achievement.

Blended learning method is a learning media that active, creative, interesting and pleasing. Garrison and Vaughn (2008) describe the basic principle of blended learning as a situation where face-to-face oral communication and the online writing communication are optimally integrated so that the strength of each are blended into a unique learning experience congruent with the context and intended educational purpose. Many educators all over the worlds develop effective learning platforms to support blended learning.

One of favorite learning platforms is Edmodo. Edmodo, as a form of technological development 
for educational purposes, is believed to be of assistance for teachers in language classrooms. Edmodo is designed very modestly, almost similar to Facebook, and provides space for teachers, students, and even parents to maximize teaching and learning process (Kongchan, 2012). Writing, which seems to be burdensome and boring, will be less demanding, as Edmodo provides a lot of convenient features to practically aid teachers and students to conduct and organize teaching writing in such a baby step (scaffolding) either in classroom sessions or students' individual learning time at home (Lara, 2013). Edmodo enables teacher and students to connect outside class. Teacher can post materials, video, quizzes, and polls at Edmodo where the students can easily comment, download or submit assignments anytime anywhere without coming to the lass. The features on Edmodo really support learning and communication between teachers and students. Parents also can have discussion directly with teachers at Edmodo because it provides class for parents

\section{METHODOLOGY}

This research was quasiexperimental research. Hamid (2011) states that quasi-experimental is kind of experiment design by certain controlling condition. The researcher chose quasi-experimental because the researcher only used the existing class and it is imposible for the researcher to change the existing so that they can monitor their children progress at class.

Another platfrom is Quipper School. The use of Quipper School aims to revolutionize the way people learn and share knowledge, by leveraging the mobile internet (Morron, 2015). Additionally, Francisco (2014) suggested that teachers should use Quipper School to vary their instructional strategies. Students learn in different ways and Quipper School offers a fun way of online learning. All the paper works is lessened through electronic grading and you can create a class and assignments in a flash. This will definitely save time and effort on the part of the teacher and the students. Furthermore, the use of Quipper School is free. It is one interactive way of e-learning.

Based on the elaboration above, the researcher makes investigation about the Effect of Using Edmodo and Quipper School in Blended Learning Method Towards Students' Writing Skill at Second Year Students' of SMAN 1 Bengkulu Tengah.

class to determine the subject of research. Moreover, experiment design is generally believed as a suitable research to examine hypothesis. This research design is chosen to explain between two variables or more or find out the effect toward another variable. In addition, this research was a quasi 
experimental with Nonequivalent Control Group. In this case, the experiment class were not chosen randomly.

The researcher used two classes: experimental class and control class. The experimental class is the class

\section{RESULT AND DISCUSSION Result}

This research was conducted in six meetings. Two meetings are for administering pre-and post-test while the rest meetings are for treatment activity. There were two different group who received different treatment. First group was experiment group who employed Edmodo and another group was control group who employed Quipper School as the technique in teaching writing.

In experiment class, the teacher did some steps in accessing Edmodo, firstly the teacher opened site Edmodo at : http://www.edmodo. com/, then the teacher signed in then making a group learning. After that the teacher invited the students to join by giving them the code of the group learning. The teacher gave the students five themes of descriptive text to be discussed and written by the students. In the process of treatment, the teacher looked that the which was given a treatment by using Edmodo in blended learning method, while control class is the class that was taught by using Quipper School in blended learning method students were anthusiast in learning writing by using Edmodo in a blended learning.

On the other hand, the teacher used Quipper School in teaching writing in control group. Since using Quipper School was almost similar to Edmodo, the teacher and the students are also sign in the website firstly before using it. Moreover, as an online platform of teaching and learning, Quipper School was only for sharing some terms of teaching and learning media such as picture and video. There was no available platform for the students to work grouply in writing a text. It only can be used to write or answer the teachers' question individually. However, there were several students looked confuse in using Quipper School. Finally, the researcher gave the post test at the last meeting.

Table 1

Data Description of Pre-Test

\begin{tabular}{|l|l|l|l|l|l|}
\hline & $\mathrm{N}$ & Range & Minimum & Maximum & Mean \\
\hline Control & 36 & 2.00 & 5.00 & 7.00 & 6.30 \\
Experiment & 36 & 2.00 & 5.00 & 7.00 & 6.11 \\
Valid N (listwise) & 36 & & & & \\
\hline
\end{tabular}


The data that was displayed in Table 4.1 showed that the minimum score of control class was 5,00 and maximum was 7,00 . It was similar to the minimum and maximum score of experiment class. Moreover, the meanscore of control class was 6,30 and experiment class was 6,11 in pre-test. The description of post test data was as follow.

Table 2

Data Description of Post-Test

\begin{tabular}{|l|l|l|l|l|l|}
\hline & $\mathrm{N}$ & Range & Minimum & Maximum & Mean \\
\hline Control & 36 & 3.00 & 5.00 & 8.00 & 6.52 \\
Experiment & 36 & 2.00 & 6.00 & 8.00 & 7.13 \\
Valid N (listwise) & 36 & & & & \\
\hline
\end{tabular}

The data description of post test revealed that the minimum score of control and experiment class were 5,00 and 6,00 while the maximum score of both classes were 8,00. Moreover, the meanscore of control class was 6,52 that was less than meanscore of experiment class. The meanscore of experiment class was 7,13 . The students' meanscore both pre-and post-test of each class was in the chart below.

\section{Chart 1. The students' Meanscore}

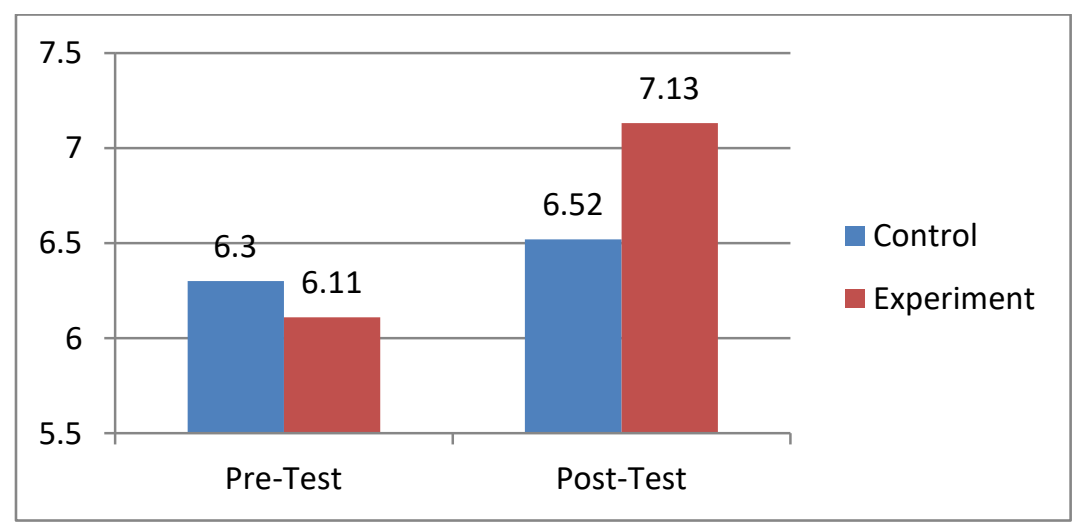

Chart 1. The students' Meanscore 
Chart 1 showed that there was a little bit difference on students' writing ability before and after the treatment in control class. The mean difference was about 0,22 in control class. However, a better improvement can be seen in experiment class after the treatment. The meanscore difference was 1,02. To know how siginficant the students' meanscore difference both control and experiment class, the researcher did hypothesis testing.

Table 3

Summary of Hypothesis Testing

\begin{tabular}{|l|l|l|l|}
\hline Post_Test Score & T & Sig. (2-tailed) & Conclusion \\
\hline Writing in General & -3.376 & .001 & Significant \\
\hline Aspect of Content & -1.907 & .041 & Significant \\
\hline Aspect of Organization & -0.745 & .459 & Not Significant \\
\hline Aspect of Language Use & -2.782 & .007 & Significant \\
\hline
\end{tabular}

Table 3 revealed that all of the post-test data was different significantly with the sig. (2-tailed) was $<0,05$. For general writing ability, the sig. (2-tailed) was 0.001 with $\mathrm{t}=-3.376$. It means that there was a significant difference on the students' witing score after using Edmodo as blended learning both experiment and control class. It can be concluded that Edmodo was effective to improve students' ability to write hortatory text both writing in general. Moreover, Edmodo was also effective to improve students' writing ability in various aspects of writing.

\section{Discussion}

The findings of research were; first, there was a significant difference on students' writing ability between the experimental
First, the result showed that sig. (2-tailed) on the aspect of content was $0,041<0,05$ which means that edmodo was effective to improve students' writing ability on the aspect of content. Edmodo can help the students to make their writing be better. The students can generate their ideas while using Edmodo. Second, the sig. (2-tailed) on the aspect of language use was $0,007<0,05$ which means Edmodo was effective to help the students to use various and appropriate language in their writing. However, Edmodo was not effective on the aspect of organization. Edmodo can not facilite the student in organizing their ideas with sig. (2-tailed) was 0.459 .

group which employed Edmodo as a blended learning method and the control group which employed Quipper School as a blended learning method after the treatment at grade 
XI of SMAN 1 Bengkulu Tengah. Second, there was a significant difference on students' writing ability of experiment group which employed Edmodo as a blended learning method in aspect of content and language use after the treatment at grade XI of SMAN 1 Bengkulu Tengah. Third, mostly students responded positively toward the use of Edmodo as blended learning to help the students to write hortatory text.

The first flow in the implementation was an initial step in which students were introduced to the course. The teacher motivated the students to get involved in the learning process followed by introducing texts to discuss. This is considered as an initial exposure to build students' knowledge as suggested by Emilia (2011). Bersin (2004)agrees that this is an introductory step for opening the course.

The present research suggests Edmodo facilitates students' engagement cognitively through Note menu. This is a delight fact since basically students' engagement accommodation in learning is one of the promises offered by e-learning or blended learning (Adrews, 2004; Coffman, 2009; Clark \& Mayer, 2011; Rank, Warren \& Millum, 2011). First, Edmodo through Note menu allowed students to work independently within the small group feature. Edmodo confirms that collaborative work in Edmodo is intended to personalize learning, in which students will have their own space for learning without any disturbance from others. The idea is supported by Reading (2008) as well as Reading and Levins (2010), that technology including learning platform should give facilities for students to work independently. Second, it enabled students to concern on their quality of work. From the documents posted it could be concluded that the students were eager to correct their works by welcoming teachers' feedback, showing that participation and work involvement took place (Reading, 2008).This is also the students' strategy to be skillful in writing as a part of cognitive engagement: how to work on tasks and how they master learning materials (Davis, Summers, \& Miller, 2012; Appleton, Christenson, and Furlong, 2008). Psychologically, the strategies are students' efforts to finish working on the tasks (Newmann, Wehlarge, \& Greene, 1992; as cited in Smiley \& Anderson, 2011). Third, it enabled students to take parts in learning situations (by getting involved into discussions). During the discussion, questionsanswers activities were commonly applied. These activities are one indicator of cognitive engagement criteria according to Reading (2008). However, having observed online and offline classes, not all students took part actively in online and offline classes. High users and low users were then identified from the frequency of students' attendance and involvement observed in Note menu.

This involvement shows student's interest towards learning (Zake et al., 2010) reflected in doing tasks or activities (Appleton et al., 2006; Reeve et al.,2004). Those who were interested commonly signed-in Edmodo very often, while the rest did not. As confirmed by some students in the interview session that they preferred offline to online learning. Fourth, it directed students 
to see Edmodo as a part of learning. The interviewees revealed that they utilized Edmodo because it had to do with academic matters. School assignments and learning preferences were the main reasons. Those observed facts, to Coates (2007) in Trowler (2010) indicate students' involvement in academic activities to enrich their schooling experience.

Another facility provided by Edmodo was interaction and meaningful tasks. Note menu provided opportunities for the students and the teacher to interact by posting something or giving comments to a post. Interaction also took place when the students post or ask genuine questions to the teacher such as when they find difficulties to access Edmodo features. Interaction in communication among technology users, in the view of Kearsley and Shneiderman (1999), is a basic requirement in language-based teaching and learning (see also Bates, 2005). The communication occurred in Note menu also indicates interaction types (Moore \& Kearsley, 1996; as cited in Lonn, 2009) experienced by the students and the teacher which are learner-content interaction, learner instructor interaction and peer interaction. While meaningful tasks are observed for Edmodo through Note menu provides students with facility for writing tasks or assignments. The writing tasks comprise of a lot of activities, started from composing,

\section{CONCLUSION}

There were significant differences on students' writing ability in the aspects of content and language use. However, there was no significant difference.The students' responses were positive toward the posting, revising to publishing writing (Brown, 2001; Gebhard, 2009; Emilia, 2011). Those heaps of activities are believed to be meaningful, which at the end coach students' ability to define the tasks and apply ideas for another task (Kearsley \& Shneiderman, 1999).

Personally, the students admitted that learning writing with Edmodo was easy and simple as well as it motivated them to write. Benefits in writing online have been claimed by Adas and Bakir (2010), Pop (2013), Lara (2013) and Abadi, Ahmadi and Mehrdad (2015) as it provides students with good writing mechanism. The students were also in agreement that Edmodo gave them unlimited time and space for learning such as learning from smartphones and learning in leisure time. Rosenberg (2001) acknowledges this as 24/7 learning as technology now has made learning accessible almost anywhere and anytime and available 24 hours a day. Besides, the students admitted that they were able to get access to multimedia learning materials. Wilson and Smilanich (2005) recognize that widen reach including access into multimedia sources is one of the advantages of blended learning. Bonk and Graham (2005) admit the fidelity of such materials in blended learning as another strength of blended learning (see also Garrison and Kanuka, 2004; Jenkins, 2006).

use of Edmodo as a blended learning. Further studies are recommended for other school levels. It seems that Edmodo is more effective than Quipper School in writing lesson since the learning platform in 
Edmodo gives facilities for the students to work independently, enables them to improve their quality

\section{REFERENCES}

Andrews, R. (2004). The impact of ICT on literacy education. New York,NY : Routledge Falmer.

Arikunto,Suharsimi.

Prosedur penelitian : Suatu pendekatan praktis. Jakarta, Indonesia : Rineka Cipta.

Deeson, Eric (1991). Dictionary of information technology. Glasgow, UK : Harper Collins Publishers.

Dudeney, G., \& Hockly, N. (2007). How to teach English with technology. Essex, UK : Pearson Education Limited.

Erben, T., Ban, R., \&Castañeda, M. (2009). Teaching english language learners through technology. Oxford, UK : Routledge.

Fauzi, Adin. (2017). The effect of edmodo on students' writing skill in recount text. IJPTE : International Journal of Pedagogy and Teacher Education Vol. 1 No.2, 115132 and has more practical, interactive, and interesting features.

Harmer, J. (2007a). How to teach English. United Kingdom, UK : Pearson Education Limited.

Hourdequin, P. (2014). Edmodo: A simple tool for blended learning. The Language Teacher. Retreived from : http://jaltpublications.org/tlt/departmen ts/tlt-wired/articles/3547edmodo-simple-toolblendedlearning, at July 10, 2017

McMillan, J., \& Schumacher, S. (1997). Research in education. a conceptual introduction . $4^{\text {th }} \mathrm{ed}$. Newyork, NY : Longman

Plato. (1999). The great dialogues of Plato. New York, NY: Penguin Books.

Raimes, A. (1983. Techniques in teaching writing. Oxford, UK : Oxford University Pres 